\title{
Urban Transformation \\ From Public and Private Space to Spaces of Hybrid Character
}

\author{
SYLKE NISSEN* \\ University of Leipzig
}

\begin{abstract}
The main characteristics of public space are accessibility and usability for all citizens. However, current developments, primarily observed in cities, suggest the loss of a clear distinction between public and private space. Instead, urban spaces of hybrid character are emerging. Spaces with public functions, like train stations, parks or pedestrian areas, are changing in character, and semi-private spaces, like malls or plazas, are spreading. In order to get a realistic view of developments this article offers a critical appraisal of recent privatisation trends followed by a brief summary. After discussing feasible reasons for the loss of private space the article considers potential implications for the future of citizenship.
\end{abstract}

Keywords: public space, privatisation, social control, security, urban studies Sociologický časopis/Czech Sociological Review, 2008, Vol. 44, No. 6: 1129-1149

\section{Introduction}

Public space is - most of all - urban space. Indeed, although the sheer notion of public space refers to an open sociological category, not spacially determined, it is hard to find any definition of the term that is not related to the city [Madanipour 1999; Carmona et al. 2003]. Beginning with the market place of mediaeval times, the public space developed in the city [see, e.g., Weber 1978; Bahrdt 1974; Habermas 1991]. The characteristics of public space - to be specified in juridical, functional, normative, social, and symbolic dimensions - are mainly assigned to urban public space [Siebel and Wehrheim 2003]. Public streets, public buildings and parks, the postulated common accessibility of public areas, the 'blasé attitude' and 'reserve' of metropolitans, first described by Georg Simmel, ${ }^{1}$ the structural symbols of consumption - all these elements take shape in the city and exert their influence on urban life and on the city's appearance.

Although it is possible to find general definitions that refer to public spaces as physical spaces that are open to all, I shall concentrate on the urban public space as the public space, for reasons of quality as well as quantity: For some time now, scientific reflections on the form and function of the public urban space have

* Direct all correspondence to: Sylke Nissen, Institute of Sociology, University of Leipzig, Beethovenstr. 15, D-04107 Leipzig, Germany, e-mail: nissen@uni-leipzig.de.

1 See 'The Metropolis and Mental Life' in Simmel [1971].

(C) Sociologický ústav AV ČR, v.v.i., Praha 2008 
been extended to focus on particular urban developments that can be summarised under the heading: the privatisation of public space [Kohn 2004]. Sociologists and political scientists remark mainly on the 'end of the public space' [Sorkin 1992] or 'the emergence of private cities' [Frug 1999; Glasze, Webster and Frantz 2005]. Observers ask, 'who owns the public space?', or 'who owns the city?' [Fainstein 2005] and not only fear the loss of public space but also see a risk to civil liberties. As publicity is perceived as a constitutive element of modern societies - so the reasoning goes - the consequences of privatisation will not remain limited to a change of proprietors but may also put pressure on the open democratic society.

The sections below concentrate first on developments observable in public spaces and broadly discussed in urban sociology. I will then summarise the manifestations of these developments by introducing the idea of 'spaces of hybrid character' as a genus that reflects different kinds of public, semi-public, semi-private and private spheres. After that I shall propose the systematic order of these spaces of hybrid character and present the causes of the observed development that help explain why they are concentrated in urban settings. Finally, I shall turn to the question of whether the changes in the built environment of cities pose a threat to citizenship.

The terms 'public space' and 'privatisation' both contain long and elaborate scientific reflections that cannot be reproduced here. Instead, we need to narrow our considerations down to pragmatic and manageable definitions of public space and privatisation in the city. Neither ownership of public areas nor buildings in the city nor the scope of public authority can fully capture the notion of public space. In addition, the question of usability arises. Peter Marcuse highlights the fact that the public space cannot be adequately qualified by differentiating between public and private ownership: '... "public space" for most policy purposes cannot be delimited simply to that space that is publicly owned. Ownership is itself a complex category, and ... I use publicly usable, rather than publicly owned, as the relevant category for analysis' [Marcuse 2003]. His interpretation corresponds to a common legal conception, according to which the public's entitlement to dispose of the property is crucial for classification as a public affair. Public spaces in common use, like streets or squares, are open to the general public for unlimited use within the framework of their functions and without the need for special permission. In addition to these rules of use, stressed by Peter Marcuse, Setha Low and Neil Smith draw attention to the rules of access: 'Public space is traditionally differentiated from private space in terms of rules of access, the source and nature of control over entry to a space, individual and collective behavior sanctioned in specific spaces, and rules of use.' [Low and Smith 2006: 3] In a similar way Rowland Atkinson defines public space 'as space to which normally people have unrestricted access and right of way' [Atkinson 2003: 1830; cf. Madanipour 1999; Nissen 2008]. These two dimensions, 'unlimited access' and 'usability', shall here serve as a definition for public space. Building on an analysis put forth by Jürgen Habermas [1991], public space is considered to 
be that space to which citizens of a polity have access and enjoy free right of use. By contrast, privatisation entails constraints on these public rights. This can happen through sales or other manners of the transfer of rights. I shall call these different forms and transitional spatial stages of public and private spaces, 'spaces of hybrid character'.

\section{Spaces of hybrid character}

Having roughly clarified the meaning of public and private spaces that this article works with, I shall now compile empirical evidence for structural changes in the classification of public and private spaces. Therefore, I shall concentrate on the built environment and look for signs that mark a diffusion of hybrid spaces in the city. These spaces are characterised by the partial or complete transfer of state or local rights to private or commercial actors as well as by the reduction or even loss of public control. The emergence of hybrid spaces is a global phenomen that has to varying degrees spreads across continents. The following overview of these developments is geared to those urban sub-spaces that are the subject of most considerations in the privatisation discourse and that mainly refer to the built environment in cities on both sides of the Atlantic: streets, parks and plazas, train stations and shopping centres, business improvement districts, and residential spaces. I assume that this regional concentration can be associated with the political logic in democratic systems that I discuss further below.

\section{Attack on the street}

One might think there is not much to say about streets in this context, as they are the most prominent public spaces and as such are not subject to particular, precisely defined uses. Streets are a city's life veins, open to all citizens, with social classes mingling. 'Streets and their sidewalks, the main public places of a city, are its most vital organs. Think of a city and what comes to mind? Its streets.' [Jacobs 1992: 29] In The Death and Life of Great American Cities, first published in 1961, Jane Jacobs sedulously describes the different facets of public life on city streets. Safety, communication, business - every kind of city life depends on the function and use of its streets. The exercise of civil liberties is linked to the street: A person who publicly shows his or her discontent takes civil protest 'to the streets' and makes use of the freedom of assembly as well as speech.

But the pressure on public streets has become manifest in the construction of new levels above and below the public street level. Canadian architect and author Trevor Boddy refers to this development as 'building the analogous city' [Boddy 1992], as the simulation of reality. So-called 'skyways' are one characteristic of the analogous city: passages, arcades or roofed-over bridges that lead through or connect buildings on the first or second level. The GUM department store in 
Moscow, where a network of paths and bridges stretches over several blocks, is one of the oldest examples for this kind of additional levels of private footpaths. With a total length of 16 kilometres, the 'Plus15' walkway system in Calgary is the world's biggest network of skyways, with department stores, shops and offices running across more than 60 blocks connected at the eponymous 15 feet above street level. ${ }^{2}$

Buildings can be linked by pedestrian walkways not only above ground but also underground. The Rockefeller Center in Manhattan stands as the prototype of this variant, where shopping arcades connecting a number of buildings below street level follow the typical Manhattan grid. The Rockefeller Plaza and its famous ice skating rink, a private space open for public use, gives the impression of having been woven into the public urban space. 'Unlike consumption-oriented privately provided public spaces, the Plaza is closely integrated into the urban fabric' [Christopherson 1994: 419]. The Rockefeller Center has been the role model for the 'Ville souterraine' in Montreal. This wide subterranean network of walkways has been built and added to since the 1960s, and it includes 2000 shops, department stores, hotels, cinemas, concert halls, restaurants, offices and appartments, several thousand parking lots, two train stations and seven subway stations spread over $3.6 \mathrm{~km}^{2}$ of floor space along tunnels of more than $30 \mathrm{~km}$ in length [cf. Boddy 1992: 146]. ' 'Private property, municipal property and property belonging to the Metro authorities abut in many different configurations even though most of the boundaries are invisible to a pedestrian who disembarks from a Metro train on MUCTC-owned ${ }^{4}$ land, enters a tunnel belonging to the city of Montreal and, from there, enters a privately owned shopping centre.' [Sijpkes and Brown 1997: 8] Citizens who move about on any of these new city levels are - depending on their line of vision - confronted with pseudo-public or pseudo-private space.

The rise of these parallel spheres and the shift of street function into the private space have both changed the character of streets as public spaces, because the disentanglement of their different uses may well lead to their desertion. 'Precisely because downtown streets are the last preserve of something approaching a mixing of all sectors of society, their replacement by the sealed realm overhead and underground has enormous implications for all aspects of political life. Constitutional guarantees of free speech and of freedom of association and assembly mean much less if there is literally no peopled public place to serve as a forum in which to act out these rights.' [Boddy 1992: 125] Consistently following Jane Jacobs' thought, the reduction of public street functions will cause the city to die off. Citizens will remain within bounded public areas, whereas unrestricted public spaces will be deserted.

\footnotetext{
2 See: www.calgary.ca/docgallery/BU/engineering_services/emaps/plus_15_network_ map.pdf, December 2008.

3 See: www.en.wikipedia.org/wiki/Ville_souterraine, December 2008.

${ }^{4}$ Montreal Urban Community Transit Corporation.
} 


\section{Parks and plazas}

City parks and plazas fulfil functions similar to public streets. Public parks and open spaces, for instance, include public gardens, recreation areas, playgrounds, athletic fields or pools that are open for public use free of charge. Usually they can be entered and used unchecked, but there are rules and regulations for park use. With respect to the city administration's task of maintaining its public gardens mainly four trends can be observed: 1) local authorities maintain the responsibility for care and (re)organisation of parks and public plazas. The effort to increase their attractiveness to middle-class citizens can be taken as one of the main goals of the local committment to the city's parks and open spaces. In order to reach this aim, public area uses are de facto redefined towards middle-class interests. 2) Private companies, activity groups or residents take over the maintainance tasks of public parks. ${ }^{5}$ 3) The complete park, plaza or other open space enters a privatisation process. 4) Public parks are neglected or even closed, and private spaces taking over their functions, but with limited access. Magret Kohn deplores 'the disappearance of public recreational facilities. New middle-class housing developments and condos often provide common recreational facilities such as parks and playgrounds. These facilities are private and accessible only to residents. Meanwhile, public alternatives - the places where black and white, working class and middle class used to come together - are closed because of shrinking user fee and weakening taxpayer support' [Kohn 2004: 8].

Each of these trends can include reconstruction and reshaping that works especially on the symbolic level [cf. Zukin 1995]. These symbols contribute to the definition of public spaces as a public usable space or as a space with reduced public access and usability. Landscape architects remodel public parks with organisation principles or questions of security being of essential interest. Lawns are replaced with 'prickly plants and flowers' [Mitchell and Staeheli 2006: 156]. Public greens are fenced in and can thus be closed after business hours. Parks are furnished according to the principles of public order. For example, benches are replaced with seating that cannot be slept on. 'Only a contortionist could sleep on the new subway benches, on the park benches with their strategically placed wrought-iron "arm-rests". Benches in parks are for people enjoying nature, waiting to go home; ... They are not for people with nowhere to go.' [Marcuse 2000: 19] Public restrooms are removed or are kept open only during the day [Mitchell and Staeheli 2006; Zukin 1995]. Public parks and greens are designed according to terms of use that remind us of the early stages of civil society long ago. After being remodeled these parks contain references to historic palace gardens like the parks of the Loire castles, Schönbrunn or Belvedere in Vienna. Much like their historic archetypes, the newly designed, former public gardens adhere

\footnotetext{
${ }^{5}$ See for example, various 'adopt-a-park' initiatives in the US.
} 
to strict principles of landscape architecture. The gardens are open to the public during certain hours or seasons and are equipped with rules and regulations that permit certain uses and prohibit others. ${ }^{6}$

As the symbolic reshaping of a public garden Bryant Park in Midtown Manhattan is one example often referred to owint to its very palpable quality. Located right next to New York Public Library the park was redefined about twenty years ago. It is a scenic landmark maintained by the Bryant Park Restoration Corporation (BPC), which 'is a not-for-profit, private management company and a cooperating business improvement district of neighboring property owners. ... BPC was formed to restore historic Bryant Park, which had suffered a severe decline in conditions in the 1970s. A 15-year agreement was signed in 1988, entrusting management and improvements to the BPC. The park reopened in 1991 after four years of renovation with a budget six times the level under prior city management. It is the largest effort in the nation to apply private management backed by private funding to a public park, and it has been a success with public, press, and nearby institutions. ${ }^{7}$ [cf. Garvin, Berens and Leinberger 1998] During renovations the park level was raised above street level, paths and lighting were repaired, the park's French garden structure was restored, and a number of Victorian kiosks reopened. At the same time new entrances were built for increased visibility from the street and opening hours were harmonised with office hours. Uniformed and plainclothes security and police officers patrol the site. Eventually, the park concept includes regular commercial usages like concerts or fashion shows, which make Bryant Park, visually and spatially, representative of middle-class consumerism. New parks like Bryant Park 'use design as an implicit code of inclusion and exclusion' [Zukin 1995: 25] by raising its appeal, bringing it closer to middleclass preferences, and thus trying to keep out undesirable clientele [Whyte 1980]. This strategy establishes 'a model of pacification by cappuccino' [Zukin 1995: 28; see also Atkinson 2003].

Plazas, small places in or around buildings, are privately owned spaces that seem as though they were public. In the US especially, plazas often emerge as a result of zoning laws and serve to compensate for consolidated building methods. In such a case, the construction permit for a downtown highrise is linked to the obligation of creating a plaza in the building's entrance area. As a result we find private areas allegedly open to the public but mostly inward oriented, exclusively designed with fountains and exotic plants as well as marble and brass elements. By cultivating this symbolism plazas attract a select, well-off clientele and can truly be called the 'front gardens to the strongholds of capitalism' [cf. Wagner 1993: 298].

\footnotetext{
${ }^{6}$ It must be remembered that these historic parks usually once belonged to aristocratic families. After having been transferred to public property, the gardens largely retained their traditional uses.

7 See: www.bryantpark.org/, December 2008.
} 
The forms of urban restructuring discussed in the above section have consequences similar to those shown for public streets. Public spaces either change their character or are replaced by private spaces, where accessibility and usability are privately controlled.

\section{Railway stations and shopping centres - railway stations as shopping centres}

Train stations and railway equipment have long been available for public use and thus are open to the general public without any second thought [cf. Hecker 2002: 6]. Most people are convinced that departure and arrival at a railway station is something that takes place in a public space. But nowadays many railway stations have been remodelled into shopping centres, and so siding and platforms often end in malls. This process also alters a station's character as a public space.

Beneath the surface of construction work we discover a change in ownership structures that redefines the 'public usability' (Marcuse) of a former public space. In Germany, for example, the 'ECE project management's corporation is a partner of the German railway company Deutschen Bahn AG and has been responsible for a number of train station reconstructions, for example, in Cologne and Hanover. The first main project of this kind involved the complete reorganisation of the central station in Leipzig. In 1997 the ECE opened up the Promenaden Hauptbahnhof Leipzig and gained nationwide attention for the spectacular three-level shopping mall that integrates the railway station's functions. ${ }^{9}$ Only the rails, the tracks and the platforms remained the property of the Deutsche Bahn AG, whereas the service counter and the waiting rooms have to be rented from ECE [Krause 2001: 93]. Today the railway station gives off the impression of a roofed mall, and everything connected with the station's transport functions seems to be visually and spatially confined. Such developments, which can be observed in a number of city centres, foster the impression that commercial usages are being increasingly superimposed on general public access to train stations [cf. Hecker 2002: 7].

Converted railway stations are a particular city-centred kind of shopping mall, compared to the malls that in the past were most often erected outside towns. There, in artificial surroundings, numerous retailers and some anchor tenants tried and still try to attract costumers. The International Council of Shopping Centres defines 'a European shopping centre as a retail property that is planned, built and managed as a single entity, comprising units and "communal" areas, with a minimum gross leasable area (GLA) of 5000 square metres $\left(\mathrm{m}^{2}\right)^{\prime}$ ' [Lambert 2006: 35]. The ICSC similarly defines a shopping centre in the United States as a

\footnotetext{
8 'The ECE Projektmanagement G.m.b.H. \& Co. KG was founded in 1965 ... The company is the European market leader in the field of inner city shopping centres.' www.ece.com/ en/wirueberuns/, December 2008.

${ }^{9}$ See: www.promenaden-hauptbahnhof-leipzig.de/en/seite/home.php, December 2008.
} 
'group of retail and other commercial establishments that is planned, developed, owned and managed as a single property, with on-site parking provided' [ICSC 2004: 2].

Not until the 1950s did the concept of fully enclosed 'shopping centres' or 'malls' find its way into American reality. Typically these malls attempt to copy in a way the downtown shopping streets. Retailers, department stores and chain operators opened up their stores alongside closed and sometimes roofed arcades that often were even given street names. 'Southdale Shopping Centre', founded in 1954 outside Minneapolis, was one of the first malls of this kind, with 72 shops and 500 parking spaces.

Today, there are more than 40000 shopping centres in the United States, ${ }_{1}^{10}$ and development there may now have peaked. In Europe the number of malls and shopping centres is still rising. In the Eastern parts of Germany in particular, after 1989, malls sprang up like mushrooms. The existence of about 560 centres (each over $8000 \mathrm{~m}^{2}$ in size ${ }^{11}$ ) gives reason for scientific research on this development as part of the privatisation debate. ${ }^{12}$

More important than the number of malls and the space they occupy, however, is their main characteristic - their claim of simulating urbanity. Mega malls from China to Canada and back, as well as small or mid-sized malls in Europe, are scientifically planned and have completely moved away from the model of the single-purpose shopping centre. Not just shops but also services and plenty of recreational activities under joint management try to offer urban amenities and entertainment, such as restaurants, hotels, cinemas, bars and nightclubs, along with ice skating rinks, golf courses, fitness and wellness centres, and even amusement parks. ${ }^{13}$ Malls - and not just the most advanced among them - represent an attempt to build artifical urban spaces in the open countryside, free from nuisances like panhandlers, dirt and bad weather [cf. Kohn 2004] In brief, the structural manifestations of business patterns can essentially also be described as attempts to enclose the city itself [cf. Siebel and Wehrheim 2003]. But this is an inappropriate way of developing urbanity. The socio-economic and built structure of a real city that has grown over a very long period of time cannot simply be copied. The 'air' of a city can hardly be captured between the walls of a mall developed from the drawing-board.

\footnotetext{
${ }^{10}$ See en.wikipedia.org/wiki/List_of_shopping_malls_in_the_United_States, December 2008.

${ }^{11}$ Data provided by the Institut für Gewerbezentren, www.shoppingcenters.de/en/home/ index.html, December 2008.

12 See, for example, Crawford [1992], Goss [1993], Jackson [1998], Kohn [2001], and Staeheli and Mitchell [2006].

${ }^{13}$ See, for example, www.westedmall.com for an idea of how management attempts to hide the consumption purposes of the malls under its quasi-urban surface.
} 


\section{Business Improvement Districts}

The growing number and increasing appeal of suburban trade centres put pressure on inner cities, a development for which Margaret Crawford coined the phrase 'spontaneous malling, a process by which urban spaces are transformed into malls without new buildings or developers' [Crawford 1992: 28]. This process can be accompagnied by the privatisation of public space unnoticed by the public. If streets are pedestrianised and buildings facing each other are linked by glass roofs we get the impression of an arcade, possibly reinforced by glass doors at either end of the pedestrian zone. Customers enter through narrow entrances that are easy to control and then move about in areas that are semi-public in character.

Coinciding with the trend of spontaneous malling, the number of inner-city 'Business Improvement Districts' has been rising. While spontaneous malling seems to occur without planning in terms of urban development, more and more BIDs are being established as a consequence of widespread discontent among retailers, service providers and other entrepreneurs over the poor competitive environment in their 'catchment area'. As a result we find semi- or pseudo-private spaces 'that are formally owned by the state, by the public, but that are subject to control and regulation by private interests' [Mitchell and Staeheli 2006: 153]. Real estate owners and entrepreneurs in the area join a partnership in order to increase the attractiveness of the downtown shopping area and to transfer the advantages ascribed to suburban shopping malls to their inner-city district. Funded by contributions from property owners, BIDs attend to the improvement of the district's appearance, send private security officers and maintenance teams to the streets, implement development plans, and enhance the marketing and promotion of their district [cf. Ward 2006]. So BIDs operate much in the way that shopping centre management does. Critising the spread of BIDs through inner cities, William Mallett speaks of the 'creation of downtown as a mall' [1994: 282].

While there are more than fifty BIDs in New York City alone, Germany can count between ten and twenty BIDs, depending on the definition [Friesecke 2006]. One reason for the small number of BIDs in Germany is the absence of a broad legal basis for their existence. Only four out of sixteen German states have yet passed BID bills. Founding a BID means that the local authority accepts a private corporation being in charge of public tasks. Thus, a BID interferes with local government structures, which could explain why German authorities react reluctantly to BID initiatives. According to Mallett, 'business improvement districts are a response to the failure of local government to adequately maintain and manage spaces of the post-industrial city' [Mallett 1994: 284]. Sovereign duties like the guarantee of law and order becomes a private responsibility: A BID finances its development plans with private sector assets and thus acquires the right to define what is allowed to happen in the public space and what is not. BIDs push forward the development of pseudo-private spaces, as described by Don Mitchell and Lynn A. Staeheli [2006: 162]. 


\section{Gated communities}

I shall finish my overview of recent changes in the built environment with a brief discussion of gated communities [cf. Low 2003]. In general, a flat or dwelling is seen as a private space per se. Windows, entrance doors, and the walls of a residence mark the borderline between private and public space. Therefore, it must be made clear that discussing gated communities does not mean concentrating on the interior of a flat but rather on dealing with the delineation between housing space and urban space. Gated communities challenge common forms of living in two ways: first, one of the main characteristics of gated communities is the fact that all its dwellings and the immediate surrounding green areas and roads are physically separated from the outside environs by walls and fences; second, gated communities do not just privatise houses and their interiors, as all open spaces inside the community's walls also belong to the homeowners or their associations. ${ }^{14}$ In the term's broadest sense, a gated community can be a tenement building - often multy-storey buildings with doormen - or closed streets and residential communities of different sizes and focus. Walled housing estates with locked entrances have become the symbol of the gated community. Setha Low defines it as follows: 'A gated community is a residential development surrounded by walls, fences, or earth banks covered with bushes and shrubs, with a secured entrance. In some cases, protection is provided by inaccessible land such as a nature reserve, and in a few cases, by a guarded bridge. ... The houses, streets, sidewalks, and other amenities are physically enclosed by these barriers ... Gated communities restrict access not just to residents' homes, but also to the use of public spaces and services - roads, parks, facilities, and open space - contained within the enclosure.' [Low 2006: 84] The management and owners of the residences in gated communities place great emphasis on security and order, which is ensured through the use of various forms of restricted access, walls or cctv systems, but also by means of a wide range of compulsory rules and regulations, so-called 'covenants, conditions and restrictions', in order to secure both good conduct and (self-)discipline on the part of the owners and the residents.

Edward Blakely and Mary Gail Snyder were among the first to take stock of gated communities in the US and classified them into three categories: lifestyle communities, prestige communities, and security zone communities [cf. Blakely and Snyder 1997]. These types of gated communities feature varying combinations of leisure, luxury and security aspects that address different target groups, from active senior citizens, to clients seeking distinction and status, to families expecting a high degree of security. The main objective of the 'common interest'

\footnotetext{
${ }^{14}$ Living inside walls immediately evokes the idea of a ghetto. The main difference between gated communities and ghettos, of course, is the voluntary segregation that residents of gated communities desire [Marcuse 1997]. There is no coercion in the decision to move into a gated community. Living in a separated residential complex is not linked to any ethnic or economic discrimination of the inhabitants.
} 
or gated housing development project is 'to protect property values by maintaining the social homogeneity of the development, by restricting individual property rights and by providing extensive security and services to commonly held property' [Christopherson 1994: 413].

In the United States the first gated communities were established in the 1960s, and, according to Blakely and Snyder, the number of them had risen to about 20000 by the end of the century [Blakely and Snyder 1999: 7]. The 2001 American Housing Survey states that almost $6 \%$ of surveyed households reported living in a walled or fenced comunity, and 3.4\% lived in communities with restricted access [cf. Low 2006: 86]. While all three types of gated community mentioned above can be found in the United States most gated communities in Asian or Latin-American metropolises typically have high security standards. Few gated communities that conform to Blakely and Snyder's definition can be found in Europe and hardly any at all in Germany. A newly built residential area called Arcadia outside Berlin perhaps comes closest to the North American type of gated community. Arcadia is the first closed and guarded estate in Germany that combines exlusiveness with security. ${ }^{15}$

Like the Business Improvement Districts, gated communities exhibit signs of 'collective self-organisation' [Glasze 2001: 169]. Homeowner associations take over duties and responsibilities such as the development of infrastructure, waste management, or street cleaning, adhering to their own principles and aiming at a reduction of local taxes [cf. McKenzie 1994]. Local authorities may at first appreciate this intervention and view the homeowner associations of closed estates as a way of sharing the burden [cf. Glasze 2003; Low 2006], but scientific observers following the development of private authorities have doubts, because the arrangement demonstrates a tendency towards the 'decline in government (the role of directly elected local government institutions) and the rise of governance - the exercise of authority by nongovernmental institutions' [Goodwin and Painter 1997: 25].

\section{The development of hybrid spaces}

The structure of urban space, seen as the physical manifestation of the idea of the public [cf. Glasze 2001: 164] is changing. Incremental shifts can be seen between public and private spaces, visibly manifested in built (fences, exclusive material), personal (security forces, cleaners), and technical signs (cctv) [cf. Nissen 2006]. These processes generate 'spaces of hybrid character', which have various mixtures of public and private structures, different degrees of accessibility, and varying extents of usability. Below I summarise six levels of shifts from public to private spaces:

${ }^{15}$ See: www.arcadia-potsdam.com/eng/start.htm, December 2008. 
Development of hybrid spaces due to privatisation tendencies

\begin{tabular}{|c|c|c|c|}
\hline & & Constraints of usability and accessibility & Example \\
\hline \multirow{6}{*}{ 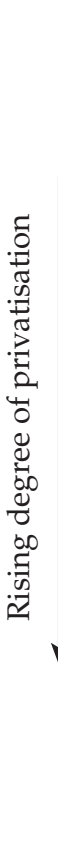 } & 1 & $\begin{array}{l}\text { Reshaping of public spaces through } \\
\text { private management, installation of signs } \\
\text { of private character; symbolic exclusion } \\
\text { through signs }\end{array}$ & $\begin{array}{l}\text { Pedestrian areas, } \\
\text { Business Improvement Dis- } \\
\text { tricts (BIDs) }\end{array}$ \\
\hline & 2 & $\begin{array}{l}\text { Semi-privatisation of public space by } \\
\text { transfer of rights of use and of mainte- } \\
\text { nance tasks on private subjects; temporary } \\
\text { exclusion through opening hours }\end{array}$ & $\begin{array}{l}\text { Redevelopment of parks and } \\
\text { public greens }\end{array}$ \\
\hline & 3 & $\begin{array}{l}\text { Construction of private spaces with lim- } \\
\text { ited public character; exclusion through } \\
\text { signs and security staff }\end{array}$ & $\begin{array}{l}\text { Skyways; plazas at the en- } \\
\text { trance of highrises }\end{array}$ \\
\hline & 4 & $\begin{array}{l}\text { Full privatisation through sale of quasi- } \\
\text { public property; exclusion through signs } \\
\text { and security staff }\end{array}$ & $\begin{array}{l}\text { Transformation of railway sta- } \\
\text { tions into shopping malls }\end{array}$ \\
\hline & 5 & $\begin{array}{l}\text { Full privatisation in the course of public } \\
\text { property sale; accessibility reduced to } \\
\text { consumers, controlled by security staff }\end{array}$ & $\begin{array}{l}\text { Sale of local property with sub- } \\
\text { sequent erection of shopping } \\
\text { centers }\end{array}$ \\
\hline & 6 & $\begin{array}{l}\text { Full privatisation in the course of public } \\
\text { property sale plus political and adminis- } \\
\text { trative spin-off from the municipal collec- } \\
\text { tive; private access only }\end{array}$ & $\begin{array}{l}\text { Gated communities, whose } \\
\text { inhabitants organise prior } \\
\text { local tasks and therefore view } \\
\text { themselvses exempt from tax } \\
\text { liability }\end{array}$ \\
\hline
\end{tabular}

The new titles to public property discussed above result in hybrids that affect the functions of urban spaces. The six gradations do not constitute singular cases, but each stands as one example of a step towards the development of hybrid spaces. In addition, they point to the consequences that arise when legal form is altered, in particular changes in the public usability of spaces [Marcuse 2003] and changes in the function of urban space as an 'indispensable medium for the implementation of democratic and social rights' [Glasze 2001: 163]. Despite empirical trends and widespread scientific viewpoint, and although the use of privatisation measures to achieve greater security and safety has been widely questioned, we must acknowledge that people's perceptions of the described developments do not always match the factual degree of privatisation. Many of the processes take place unnoticed by citizens, travellers, customers or residents. People even accept being under covert observation by cctv or security guards (in so far as they are even aware of being watched) because they feel it may enhance safety and serves public order. Simplistic judgements, such as, there is nothing to fear from cctv or other modes of increasing surveillance if you are not doing anything wrong, are naïve, as 'this really depends on who is defining what is wrong' [cf. Atkinson 2003: 1833]. 


\section{Who pushes for privatisation and why?}

Given the growing perception and awareness of the loss of public space, we have to inquire about the factors contributing to hybridising processes. This question can only be answered by looking at the actors behind the developments. Urban hybrid spaces do not simply emerge as a result of economic restructuring or as a byproduct of individualisation, both of which are tendencies that visibly shape urban society. But privatisation in cities does not just happen. It is promoted and steered.

The administration and the redesignation or sale of public urban space are responsibilities that lie mainly in the hands of local authorities. In democracies, city administrations, i.e. local political and administrative representatives, are held accountable by the public and bear a great part of responsibility for the development of hybrid spaces. ${ }^{16}$ It is therefore necessary to look at the motives and driving forces at the level of local actors.

\section{The reasons for privatisation: the reduction of local public debt}

Political representatives of a municipality have to focus on the protection or reestablishment of the political ability to act and strive for success in the competition among cities. In selling public property, mayors and heads of administration or treasurers are not just looking after local welfare. Elected officials also pay attention to the protection of (their individual) political interests and are necessarily concerned about their chances at the next local elections. This means that sometimes they promote populist ideas or cater to supposed public opion [cf. Nissen 2002]. ${ }^{17}$ For example, a local government that for the sake of urban openness advocates less security and more tolerance for the nuisances that are a part of everyday streetlife would be reducing its chances of being reelected.

In this view, transformation of public space can increase the probability of achieving local and consequently also individual aims. Most municipalities are in tough financial situations, and the privatisation of public property can help relieve budget pressure. ${ }^{18}$ Local treasurers sell real estate, essentially 'the family

\footnotetext{
${ }_{16}$ Train stations are an exception to this rule. Railroad property is only quasi-public, and railway companies in many countries are no longer public corporations, although for historic reasons railway traffic has a lasting public character. Nevertheless legal opinion in Germany judges the corporate reforms in the railway sector as the privatisation of the organisational form but not of duties and responsibilities [cf. Hecker 2002: 6].

17 This mechanism can be observed in different contexts. See, for example, the discussion about the freedom of movement for workers from new EEC member states [Belke and Hebler 2002: 166].

${ }^{18}$ Relieving the city of the burden of public property follows the same logic as 'new public management' initiatives [cf. Osborne and Gaebler 1992] that see local authorities as service providers.
} 
silver', and assign maintenance duties to private investors. The German city of Dresden is one case in point: In 2006 the local authority sold its housing stock of 48000 dwellings to an American private equity firm, the Fortress Investment Group LLC. The city received 1.7 billion Euro for the sale and virtually overnight became debt-free [Landler 2006].

Municipalities try to sell not just apartment buildings but also local facilities like hospitals or public transit, and then leave the city with greater manoeuvring room. The sales revenue enters the books on short notice, that is, just in time for the next local elections. The costs that could arise from necessary rental agreements or lease contracts will only rise slowly to a level where they become noticeable. At the same time, the sale reduces the scope of local responsibilities, which enables political actors to score points by streamlining administration. However, this hope for release may ultimately prove elusive for two reasons. First, the privatisation of public property does not free a municpality from its legal responsibility [Wolf 1999: 12]..${ }^{19}$ Second, the public may not recognise the factual reduction of local political responsibility as such. If voters stick to the conviction that municipalities still hold responsibility for local affairs, the local actor's loss of influence in the given area may negatively affect his or her track record. In any case, it is necessary to note that, contrary to politicians' expectations, in hybrid spaces the given authority's responsibility remains nearly unchanged, but its ability to take action is reduced, and so is its influence on the city's socio-spatial development.

\section{Reasons for privatisation: security}

The architecture of safety seems to be one of the most visible developments in privatised spaces. Public green areas, fenced in but to be overlooked and guarded, private security officers on patrol in malls and shopping centres, skywalks limiting access to particular clientele, and the ubiquitous cctv are only some examples of the safety-driven rearrangement of urban spaces. To ensure citizens feel protected and to create the impression that the city's development is under control, a local concept of safety, cleanliness and service is seen as an answer to people's demands. A sense of security seems to be decisive for the citizens' opinion about the growing architecture of safety. This sense of security, however, is not so much influenced by the real security situation but by the subjective appraisal of individuals. Even though politicians like to advertise falling crime figures, this may not conform with the public's view if people feel increasingly insecure and see

\footnotetext{
19 Wolf's legal opinion refers to the responsibility of the public authority for airspace security in the case of two airplanes crashing after having been misguided by a private provider of air navigation services. See: www.iasa.com.au/folders/Publications/Legal_Issues/ skyguide-sequel.html (December 2008). Also see the sentence delivered on 26 June 2006 by the German District Council of Konstanz in Bashkirian Airlines vs. the Federal Republic of Germany.
} 
themselves - though largely at odds with the facts ${ }^{20}$ - as potential crime victims [van Dijk et al. 2005]. Called 'moral panic' in criminology [Cohen 1972], this phenomenon mainly depends on the occurrence of specific forms of crime, how they are presented in the mass media, and the fact that there is a receptive audience for these presentations [cf. Albrecht 2002; Foster 2003].

It is difficult for local administrations to bridge the gap between the real security situation and the citizens' sense of security. But even so, fighting crime is an important and promising political arena and for various reasons: Police work can be controlled and managed locally. Citizens support funding security more than other expenses. A majority of the population benefits from declining crime rates and in return places general trust in its local representatives [cf. Nissen 2002]. Thus, in the field of crime policies political actors are able to demonstrate their ability to take action to compensate for their inability to do so in other policy areas [cf. Siebel and Wehrheim 2003]. Fighting crime has consequently become one of the most prominent communal tasks, and not just in the US, where the 'broken windows' discussion triggered it all off [Wilson and Kelling 1982; Kelling and Bratton 1998].

However, if a local administration is overwhelmed by the task of providing security, and the police's financial and human resources are insufficient to increase the sense of security, the municipality runs the risk of being unable to satisfy citizens' expectations. In this case, the municipality may see privatising public property as a way of reducing or shifting the responsibility for maintaining a safe environment to the new owner. At this stage of development urban safety is barely a political task any more. Instead, public safety is increasingly the subject of activities in the private sphere, is secured less by the police, and lies more and more outside democratic control. Many observers object to the legal, political and social implications of ever greater tendencies towards privatisation. "The "filtering" of the undesirable from the desirable users brings on an atmosphere of discrimination that is detrimental to the well-being of both marginal and mainstream groups.' [Sijpkes and Brown 1997: 8f] The city becomes generally less open to and less intended for use by all citizens and is increasingly restricted to 'citizen-consumers' [Clarke et al. 2007]. Access and inclusion more and more depend on people's ability to convincingly assume the role of the consumer. The waning of the public city and the intensified commercialisation of city centres, which is fed by the abandonment of public property, are bringing about a new definition of the citizen's role. A citizen is one who acquires mobile or immobile property. Thus, in hybrid urban spaces the notion of the citizen is again beginning to be tied to property. ${ }^{21}$

${ }^{20}$ For more on the methods and problems of measuring crime, see Nissen [2003].

${ }^{21}$ For an early discussion of citizenship and the rights of citizens, see Marshall [1976]. 


\section{The privatisation of citizenship?}

When we take a closer look at the loss of the public and the potential threat to (local) democracy, is it true that the citoyen is consequently being transformed into a consumer-citizen? Evan McKenzie's notion of 'Privatopia' holds many negative connotations with respect to the changes to public space. His scenario of a privatised future is based on empirical developments mainly observed in urban settings. The strengthening in particular of elements that undermine the still dominant model of the free city is what seems to make the scenario so frightening. William Fulton sees life in Los Angeles as 'a constant caravan between the residential cocoon, where citizenship is exercised only in narrow, self-interested ways, and the spending and working cocoons, where citizenship is totally surrendered to the commercial forces that run the place' [Fulton 1997: 342]. Aside from the fact that images like this depict a situation but do not explain its emergence, this kind of criticism is usually coupled with warnings about a divide arising in society, the beginnings of which are seen in urban societies, segregated along ethnic, social, and economic lines [cf. Marcuse 1989; Mollenkopf and Castells 1991].

Behind these descriptions is the negative utopia of the privatised city, not just spatially manifesting the divide in society, but moreover serving as evidence of incapacity at the local political level. It is argued that by relinquishing or selling public space the local entity as the 'birthplace of democracy' fails. New urban spaces open up to imperatives from the commercial private sector and neglect the democratic role of the municipality to the detriment of citizenship. Following this logic the citizen or citoyen is replaced by the solvent consumer.

However, there is not sufficient quantitative evidence to judge the presumed tendency of cities towards becoming 'Privatopias'. There is of course data on the numbers of shopping malls and gated communities. But many questions remain unanswered. What share of the population is in fact hit permanently by those mechanisms of exclusion that emanate from hybrid spaces? Can various forms of hybrid spaces in principle be treated as pre-stages to full privatisation? Do the observations represent a global trend towards privatisation? We simply do not know how strong a cause for concern the disappearance of public spaces really is. Instead of further nurishing a feeling of threat and ineluctability I want to point out three aspects associated with the public space whose relevance in my opinion are not yet sufficiently appreciated:

1) Spatial exclusion is not a new phenomenon and cannot just be linked to privatisation trends. Town walls and gates have been symbols of closure and sealing-off for centuries. I have alreay drawn attention to palace gardens as historic predecessors to urban greens. Gated communities, too, evoke some analogies to earlier forms of spatial and thus social separation like for example allotment gardens. For centuries there have been forms of voluntary and involuntary segregation. Spatial separation has several historical precursors that, like today's hybrid spaces, reduced accessibility and usability, established exclusion and exclusiveness, and ensured a sense of security. Nonetheless, the public 
prevailed as a feature of modern civil society, despite experiences of privatisation and spatial separation [Bahrdt 1974].

2) It would be a fallacy to assume public space has always been or is today open to every member of society equally. Current hybridisation tendencies may bring about a yearning for the 'good old days', when the city perhaps appeared to be open and accessible to all. But in fact urban spaces have never been free and for use by everyone [cf. Jackson 1998: 176]. At different stages in history, different social groups or classes have been denied access to and use of public spaces. By law, through symbolic acts, or simply from fear of force, young people, old people, women, the disabled, homosexuals, or members of ethnic minorities have suffered limitations on their freedom of movement. 'Public space has always been controlled. It has never been truly "free" and "open".' [Lees 1998: 239; Kohn 2001, 2004; Mitchell and Staeheli 2006]. Dominated by certain people or groups, while always excluding others, 'public space does not exist' [Dijkstra 1997]. It remains an ideal unfulfilled.

3) Finally, an adequate discussion of the structural transformation of public and private urban spheres has to consider all those public spheres recently gained through the emergence of the World Wide Web. Through global networks and the lack of the need for physical presence, the World Wide Web develops a public sphere uncomparable to the public space of a market place. Needless to say, the argument holds that the internet, too, is not open to every citizen equally [cf. Mitchell 1995]. But examples like the Vancouver Public Library speak a different language. Everyone who enters the rooms of that library enjoys free access to the internet [Lees 1998]. Since 1995 libraries in the US, Canada and also Ireland have benefited from Libraries Online!, an initiative sponsored by Microsoft offering free internet access in public libraries. ${ }^{22} \mathrm{In}$ other words the virtual space of the internet does not represent a closure but an opening. Exclusionary tendencies in hybrid spaces are contrasted in this case by the growing inclusiveness of the World Wide Web. Lees reasons: 'First, public space is being opened up in new and complex ways; second, the control of urban public space can almost always be countered, subverted, and resisted.' [Lees 1998: 239] Those spaces that are currently the focus of attention may lose some of their relevance for evaluating democracy in the future and may in part be replaced by new public spheres.

It is conceivable that semi-public or privatised spaces could immediately revitalise their function as spheres of democratic structures if necessary. If, for example, people were to see a need to restart, for example, the 'Monday demonstrations $^{\prime 23}$ that East Germans used to hold, it is likely that in an effort to defend

${ }^{22}$ Further information on this programme can be found at the Microsoft and the Bill and Melinda Gates Foundation websites: www.microsoft.com/presspass/press/1996/oct96/ lol.mspx; www.gatesfoundation.org/UnitedStates/USLibraryProgram/, December 2008. ${ }^{23}$ This refers to the series of peaceful demonstrations in East Germany in 1989 that took place every Monday evening calling for the fall of the Berlin Wall. 
democracy the organisers would seek (and find) ways to avoid the ban from pedestrian areas or shopping malls, and that they would be willing to infringe on the domiciliary rights of the private owners of the premises.

The implications of the spread of hybrid forms should not be treated lightly. The changes express a structural transformation of public and private spaces, and thus summarising them under the umbrella term of 'loss of the public' would be too simple. Instead, the consequences of this development should be watched closely, and any judgement must also take into account emerging new public spheres.

SYLKE Nissen teaches sociology and political science at the universities of Frankfurt/Main and Leipzig. She is co-editor of the journal Soziologie. Her recent publications include 'European Identity and the Future of Europe' (pp. 155-174 in Europe in Motion, edited by Maurizio Bach, Christian Lahusen, Georg Vobruba, 2006: Berlin: Edition Sigma, pp. 155-174) and 'Hybridräume. Zum Wandel von Öffentlichkeit und Privatheit in der Stadt', Archives Européennes de Sociologie, XLIX, 2 (2008): 277-306.

\section{References}

Albrecht, Hans-Jörg. 2002. 'Immigration, Crime and Unsafety.' Pp. 159-185 in Crime and Insecurity. The Governance of Safety in Europe, edited by A. Crawford. Cullompton and Portland: Willan Publishing.

Atkinson, Rowland. 2003. 'Domestication by Cappucino or a Revenge on Urban Space? Control and Empowerment in the Management of Public Spaces.' Urban Studies 40: 1829-1843.

Bahrdt, Hans Paul. 1974. Die moderne Großstadt. Munich: Nymphenburger Verlagshandlung.

Belke, Ansgar and Martin Hebler. 2002. EU-Osterweiterung, Euro und Arbeitsmärkte. Munich: Oldenbourg.

Blakely, Edward J. and Mary Gail Snyder. 1997. 'Putting up the Gates.' Shelterforce Online, May/June 1997. Retrieved December 2008 (www.nhi.org/online/issues/93/gates. html).

Blakely, Edward J. and Mary Gail Snyder. 1999. Fortress America. Gated Communities in the United States. Washington, D.C.: The Brookings Institution.

Boddy, Trevor. 1992. 'Underground and Overhead: Building the Analogous City.' Pp. 123-153 in Variations on a Theme Park, edited by Michael Sorkin. New York: Hill \& Wang.

Carmona, Matthew, Tim Heath, Taner Oc and Steve Tiesdell. 2003. Public Places - Urban Spaces. Oxford: Elsevier.

Christopherson, Susan. 1994. 'The Fortress City: Privatized Spaces, Consumer Citizenship.' Pp. 409-427 in Post-Fordism, edited by Ash Amin. Oxford, Cambridge: Blackwell.

Cohen, Stanley. 1972. Folk Devils and Moral Panics. London: Mac Gibbon and Kee.

Clarke, John, Janet Newman, Nick Smith, Elizabeth Vidler and Louise Westmarland. 2007. Creating Citizen-Consumers: Changing Publics \& Changing Public Services. London: Sage. 
Crawford, Margaret. 1992. 'The World in a Shopping Mall.' Pp. 3-30 in Variations on a Theme Park, edited by Michael Sorkin. New York: Hill \& Wang.

Dijkstra, Rients. 1997. 'Public Space Does Not Exist.' Unpublished paper. Presented at the workshop of the Styrian Architects' Association. Graz.

Fainstein, Susan S. 2005. 'Planning Theory and the City.' Journal of Planning Education and Research 25: 121-130.

Foster, Janet. 2003. 'Kriminalität und Strafverfolgung in London. Zur Interdependenz von öffentlichem Klima, Medien und Politik.' Pp. 13-42 in Kriminalität und Sicherheitspolitik. Analysen aus London, Paris, Berlin und New York, edited by Sylke Nissen. Opladen: Leske und Budrich.

Friesecke, Frank. 2006. 'Revitalization of Urban Areas through Business Improvement Districts (BIDs) - Trends and Expectations for Shrinking Cities.' Paper presented at the 5th FIG Regional Conference 'Promoting Land Administration and Good Governance', Accra, Ghana, 8-11 March 2006. Retrieved December 2008 (www.fig. net/pub/accra/papers/ts10/ts10_02_friesecke.pdf).

Frug, Gerald E. 1999. 'The Emergence of Private Cities in America.' Kritische Justiz 32: 578-586.

Fulton, William. 1997. The Reluctant Metropolis. Point Arena, Cal.: Solano Press Books.

Garvin, Alexander, Gayle Berens and Christopher B. Leinberger. 1998. Urban Parks and Open Space. Washington D.C.: ULI - The Urban Land Institute.

Glasze, Georg. 2001. 'Privatisierung öffentlicher Räume? Einkaufszentren, Business Improvement Districts und geschlossene Wohnkomplexe.' Berichte zur deutschen Landeskunde 75: 160-177.

Glasze, Georg. 2003. ‘Private Neighbourhoods as Club Economies and Shareholder Democracies.' BelGeo: Privatisation of Urban Spaces in Contemporary European Cities (thematic issue): 87-98.

Glasze, Georg, Chris Webster and Klaus Frantz. 2005. Private Cities: Global and Local Perspectives. London: Routledge.

Goodwin, Mark and Joe Painter. 1997. 'Concrete Research, Urban Regimes and Regulation Theory.' Pp. 13-29 in Reconstructing Urban Regime Theory. Regulating Urban Politics in a Global Economy, edited by Mickey Laurey. Thousand Oaks: Sage.

Goss, Jon. 1993. 'The "Magic of the Mall": An Analysis of Form, Function, and Meaning in the Contemporary Built Environment.' Annals of the Association of American Geographers: 18-47.

Habermas, Jürgen. 1991. The Structural Transformation of the Public Sphere: An Inquiry into a Category of Bourgeois Society. Cambridge, MA: MIT Press

Hecker, Wolfgang. 2002. Bahnhöfe - Öffentlicher Raum für alle? Zur rechtlichen Stellung der Bahnhöfe, dem Recht auf Zugang und Aufenthalt sowie der Zulässigkeit von Hausverbot. Rechtsgutachten im Auftrag der Bundesarbeitsgemeinschaft Wohnungslosenhilfe e.V. Bielefeld: VSH Verlag.

ICSC International Council of Shopping Centers. 2004. ICSC Shopping Center Definitions. Basic Configurations and Types for the United States. Retrieved December 2008 (www.icsc. org/srch/lib/USDefinitions.pdf).

Jackson, Peter. 1998. 'Domesticating the Street: The Contested Spaces of the High Street and the Mall.' Pp. 176-191 in Images of the Street, edited by Nicholas R. Fyfe. London, New York: Routledge.

Jacobs, Jane. 1992. The Death and Life of Great American Cities. New York: Random House, Vintage Books.

Kelling, George L. and William J. Bratton. 1998. 'Declining Crime Rates: Insiders' Views of the New York City Story.' The Journal of Criminal Law and Criminology 88 (4): 1217-1232. 
Kohn, Margaret. 2001. 'The Mauling of Public Space.' Dissent: 71-77.

Kohn, Margaret. 2004. Brave New Neighborhoods. New York, London: Routledge.

Krause, Mandy. 2001. 'Leipzig Goes West: Gefahrenabwehrverordnungen - Platzverweise - "vertreibende Hilfe" dargestellt am Beispiel Leipzigs.' Pp. 80-103 in Wem gehört der öffentliche Raum? Zum Umgang mit Armen und Randgruppen in Deutschlands Städten, edited by Titus Simon. Opladen: Leske and Budrich.

Lambert, Jean. 2006. 'One Step Closer to a Pan-European Shopping Center Standard.' Research Review 13: 35-40. Retrieved June 2008 (http://www.icsc.org/srch/lib/euro_ standard_only.pdf)

Landler, Mark. 2006. 'German Public Housing in Private Hands.' New York Times. 5 May 2006. Retrieved December 2008 (www.nytimes.com/2006/05/05/business / worldbusiness /05property.html?_r=2\&pagewanted=print)

Lees, Loretta. 1998. 'Urban Renaissance and the Street: Spaces of Control and Contestation.' Pp. 236-253 in Images of the Street, edited by Nicholas R. Fyfe. London, New York: Routledge.

Low, Setha. 2003. Behind the Gates. London: Routledge.

Low, Setha. 2006. 'How Private Interests Take Over Public Space: Zoning, Taxes, and Incorporation of Gated Communities.' Pp. 81-103 in The Politics of Public Space, edited by Setha Low and Neil Smith. New York, London: Routledge.

Low, Setha and Neil Smith. 2006. 'Introduction: The Imperative of Public Space.' Pp. 1-16 in The Politics of Public Space, edited by Setha Low and Neil Smith. New York, London: Routledge.

Madanipour, Ali. 1999. 'Why Are the Design and Development of Public Spaces Significant for Cities?' Environment and Planning B: Planning and Design 26 (6): 879-891.

Mallett, William J. 1994. 'Managing the Post-industrial City: Business Improvement Districts in the United States.' Area 26: 276-287.

Marcuse, Peter. 1989. "'Dual City": A Muddy Metaphor for a Quartered City.' International Journal of Urban and Regional Research 13: 697-708.

Marcuse, Peter. 1997. 'The Enclave, the Citadel, and the Ghetto: What Has Changed in the Post-Fordist US City.' Urban Affairs Review 33 (2): 228-264.

Marcuse, Peter. 2000. 'Benches.' Pp. 18-19 in City A-Z, edited by Steve Pile and Nigel Thrift. London: Routledge.

Marcuse, Peter. 2003. 'The Threats to Publicly Usable Space in a Time of Contraction.' Wolkenkuckucksheim. Internationale Zeitschrift für Theorie und Wissenschaft der Architektur 8. Retrieved December 2008 (www.tu-cottbus.de/BTU/Fak2/TheoArch/wolke/eng/ Subjects/subject031.htm).

Marshall, Thomas H. 1976. Class, Citizenship and Social Development. Westport, CT.: Greenwood Press.

McKenzie, Evan. 1994. Privatopia. New Haven, London: Yale University Press.

Mitchell, Don. 1995. 'The End of Public Space?' Annals of the Association of American Geographers 85: 108-133.

Mitchell, Don and Lynn A. Staeheli. 2006. 'Clean and Safe? Property Redevelopment, Public Space, and Homelessness in Downtown San Diego.' Pp. 143-175 in The Politics of Public Space, edited by Setha Low and Neil Smith. New York, London: Routledge.

Mollenkopf, John H. and Manuel Castells (eds.). 1991. Dual City. Restructuring New York. New York: Russell Sage Foundation.

Nissen, Sylke. 2002. Die regierbare Stadt. Metropolenpolitik als Konstruktion lösbarer Probleme. New York, London und Berlin im Vergleich. Wiesbaden: Westdeutscher Verlag.

Nissen, Sylke. 2003. 'Vom Nutzen des Kriminalitätsschadens, oder: Verbrechen zahlt sich 
aus.' Pp. 103-126 in Kriminalität und Sicherheitspolitik. Analysen aus London, Paris, Berlin und New York, edited by Sylke Nissen. Opladen: Leske und Budrich.

Nissen, Sylke. 2006. 'Die Privatisierung des öffentlichen Raums.' Pp. 130-145 in Eigentum und Handlungsrechte im Zeitalter der Propertization, edited by Hannes Siegrist. Leipzig: Leipziger Universitätsverlag.

Nissen, Sylke. 2008. 'Hybridräume. Zum Wandel von Öffentlichkeit und Privatheit in der Stadt.' Archives Européennes de Sociologie 49 (2): 277-306.

Osborne, David and Ted Gaebler. 1992. 'Reinventing Government: How the Entrepreneurial Spirit is Transforming the Public Sector.' Reading, Mass.: AddisonWesley Publ. Co.

Siebel, Walter and Jan Wehrheim. 2003. 'Security and the Urban Public Sphere.' Deutsche Zeitschrift für Kommunalwissenschaften 42 (1). Retrieved December 2008 (www.difu. de/index.shtml? / publikationen/dfk/).

Sijpkes, Pieter and David Brown. 1997. 'Montreal's Indoor City: 35 Years of Development.' Paper presented at the 7th International Conference on Underground Space, Montreal, September 29 to October 3 1997. Retrieved December 2008 (www.ovi. umontreal.ca/documents/ovi_psijpkes-dbrown.pdf).

Simmel, Georg. 1971 (1903). On Individuality and Social Forms. Chicago: University of Chicago Press.

Sorkin, Michael (ed.). 1992. Variations on a Theme Park. The New American City and the End of Public Space. New York: Hill \& Wang

Staeheli, Lynn A. and Don Mitchell. 2006. 'USA's Destiny? Regulating Space and Creating Community in American Shopping Malls.' Urban Studies 43: 977-992.

van Dijk, Jan, Robert Manchin, John van Kesteren, Sami Nevala and Gergely Hideg. 2005. The Burden of Crime in the EU. Research Report: A Comparative Analysis of the European Crime and Safety Survey (EU ICS). Retrieved December 2008.

Wagner, Monika. 1993. 'Privatisierung von Kunst und Natur im öffentlichen Raum. Die Plazas von Manhattan.' Pp. 286-299 in New York. Strukturen einer Metropole, edited by Hartmut Häußermann and Walter Siebel. Frankfurt/Main: Suhrkamp.

Ward, Kevin. 2006. "“Policies in Motion”, Urban Management and State Restructuring: The Trans-Local Expansion of Business Improvement Districts.' International Journal of Urban and Regional Research 30: 54-75.

Weber, Max. 1978. Economy and Society: An Outline of Interpretive Sociology. Berkeley: University of California Press.

Whyte, William. 1980. Social Life of Small Urban Spaces. Washington, D.C.: Conservation Foundation.

Wilson, James Q. and George L. Kelling. 1982. 'Broken Windows.' Atlantic Monthly: 29-38.

Wolf, Joachim. 1999. Das Recht des Lebens auf der Straße. Ein Rechtsgutachten zur Privatisierung öffentlicher Flächen und zum Grundrechtsschutz wohnungsloser Menschen. Dortmund: ILS.

Zukin, Sharon. 1995. The Culture of Cities. Oxford: Blackwell. 

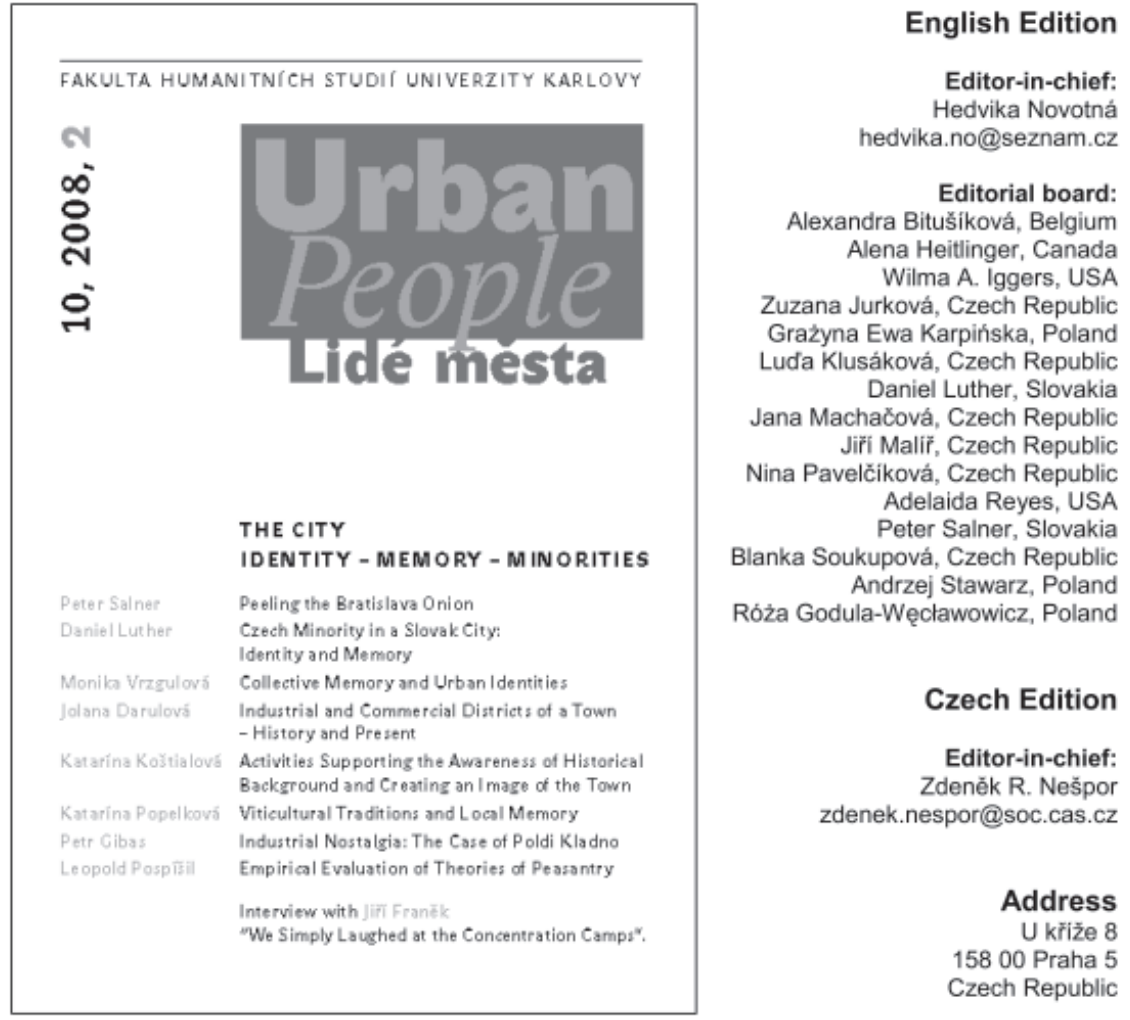

Editor-in-chief: Hedvika Novotná hedvika.no@seznam.cz

Editorial board: Alexandra Bitušíková, Belgium Alena Heitlinger, Canada Wilma A. Iggers, USA Zuzana Jurková, Czech Republic Grażyna Ewa Karpińska, Poland Luda Klusáková, Czech Republic Daniel Luther, Slovakia Jana Machađ̌ová, Czech Republic Jirî Malî́, Czech Republic Nina Pavelčiková, Czech Republic Adelaida Reyes, USA Peter Salner, Slovakia Blanka Soukupová, Czech Republic Andrzej Stawarz, Poland Róża Godula-Węclawowicz, Poland

\section{Czech Edition}

Editor-in-chief: Zdeněk R. Nešpor zdenek.nespor@soc.cas.cz

Address

U křiže 8

15800 Praha 5 Czech Republic

\section{Urban People / Lidé města}

Peer-reviewed scholarly journal is focused on anthropological studies with emphasis on urban studies and related social sciences and humanities. It is the only anthropological journal published in the Czech Republic. It is published three times a year, twice in Czech (in May and December) and once in English (in September).

The editorial board accepts original, previously unpublished texts in the anthropological studies in the form of articles, essays, review articles, reviews, reports, or other types of scientific publications. Texts in Czech or Slovak languages are published in the Czech volumes of the journal; texts in English in the English

volumes of the journal. Articles, essays and review articles are submitted for anonymous reviewing process. The editorial board decides on the publication of materials, reviews and reports.

Distribution: Nakladatelstvi Aleš Čeněk, Prvniho pluku 17, 18000 Praha 8. 